Review Article レビュー論文ーシリーズ 131

Invited Peer-Reviewed Article 招待査読論文

\title{
Trends of Color Research in Consumer Behavior 消費者行動領域における色彩研究の潮流
}

\author{
Hisashi Kawamata*1 \\ 早稲田大学 商学部 \\ 河股 久司
}

${ }^{* 1}$ School of Commerce, Waseda University, Japan, kawamatah@aoni.waseda.jp

\begin{abstract}
This study identifies recent trends in research on color by reviewing the literature since 2015. A review was conducted on four major categories of color research: hue, lightness, chroma, and monochrome vs. color. An examination of the relationship between color and marketing mix (4P's) revealed that, while hue has been studied for every component of the marketing mix, brightness literature is limited to the product component of the marketing mix and chroma literature is limited to product and place. An analysis focusing on multisensory cross-modal effects showed that there are studies on color related to taste, auditory effects, and haptics, but a lack of research investigating the relationship between color and olfactory effects. In summary, this study identifies gaps in the existing literature on color and marketing mix and on color and multisensory cross-modal effects.
\end{abstract}

Keyword : Color, Hue, Brightness, Saturation, Cross-modal

要約 : 本論文は, 2015 年以降の色彩に関する研究をレビューすることによって, 近年の色彩研究の潮流を把握することを目的 とする。色に関する研究を, 色の三属性である色相・明度·彩度それぞれの視点による研究と, モノクロとカラ一の比較による 研究の 4 つに大別してレビューを行った。その上で, 色とマーケティングミックスとの関連を検討したところ, 今回のレビュー の範囲においては, 色相に関する研究は, マ一ケティングミックスの各要素と関連するものが実施されていることが確認でき た。一方, 彩度に関してはマーケティングミックスのうち製品との関連のみ, 明度に関しては製品と流通チャネルとの関連に限 られた研究が実施されていることが明らかになった。また, クロスモーダル効果に着目すると, 色と味覚や聴覚, 触覚との関連 についての研究はなされているものの, 色と嗅覚との関係を検討している研究がないことが確認された。

キーワード : 色, 色相, 明度, 彩度, クロスモーダル

Information : Received 1 June 2021; Accepted 16 June 2021

\section{I. はじめに}

コカ・コーラの赤色の缶, スターバックスの緑色のロ ゴマーク, Twitter の水色のアイコンマークなど製品や サービスには, 各ブランドの特徴となる色が用いられて いる。また, 白物家電と呼ばれる冷蔵庫や炊飯器, さら に白や水色がメインカラーであったマスクも豊かなカラー バリエーションを持つようになった。

学術的な研究に目を向けると, 製品パッケージやロゴ マークなど，さまざまなマーケティング要素に用いられ る色が消費者に与える影響について, 多くの研究で検討 がなされている。中でも 21 世紀初めから消費者行動の
文脈で色への関心が高まっており（Labrecque, 2020，色 が与える身体的あるいは意味的な影響に着目した研究が 精力的に進められている。その背景として, 消費者の五 感への訴求を中心に据える, 感覚マーケティングの隆盛 が挙げられる。五感の中でも視覚は, ほかの感覚に比べ てその優位性が高いことから (Krishna, 2012), 視覚に影 響をもたらす色に関する研究が盛んに進められていると 考えられる。このような潮流の中で, 2020 年に『Psychology and Marketing』誌で色に関する特集号が組まれており， 消費者行動研究において色に対する関心が極めて高いこ とが理解できる。そこで本論文は, マーケティングに関 連した色を対象としたレビュー論文である Elliot（2015） 以降に絞り, 色が消費者行動に与える影響に関する研究 
Review Article レビュー論文ーシリーズ 131

を整理する。

本論文の構成は以下の通りである。第 2 章では，色を 決定づける三属性について紹介し, 本論文のレビューの 枠組みを提示する。第 3 章から第 5 章では色に関連する 既存研究を整理する。そして, 最後の第 6 章で, これら の研究をまとめ, 今後の課題について議論する。

\section{II. 色の三属性とレビューの枠組み}

色は，色相（hue）・明度（brightness, value）・彩度 （saturation, chroma）と呼ばれる 3 つの属性の変化により 決定する。色相は, 赤や青など色調の違いを示すもので, 対象から放たれる光の波長によって変化する。色相に基

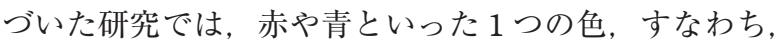
単色の効果のみならず，複数色を用いた配色の効果に着 目した研究も存在する。そこで，色相に関する研究を単 色の効果と配色の効果に分け第 3 章で整理する。

2 つ目の属性である明度は色の明るさを示すものであ り, 光の強度に対応する。明度が高くなることで白色に 近づき，明度が低くなることで黒色に近づく。そして， 3つ目の属性である彩度は色の鮮やかさを示す。彩度は, 純度と呼ばれる光刺激の特性に対応し (Ohyama \& Saito, 2009)，彩度が高くなると鮮やかな色に，低くなるとく すんだ色になる。この明度や彩度に着目した研究は第 4 章で取り上げる。

さらに本論文では，モノクロとカラーを比較した研究 もレビューする。色を決定づける三属性のうち，カラー が色相・明度・彩度すべてを持ち合わせる有彩色である のに対し，モノクロは明度のみを持つ無彩色である。そ のためモノクロとカラーを比較した研究は, 色相と彩度 の 2 つの属性の影響の変化が消費者に与える影響を検討 した研究となる。本論文では，色の三属性をそれぞれ分 けてレビューするため, 複数の属性の変化を取り扱うモ ノクロとカラーを比較した研究は, 第 5 章で別個に取り 扱う。

以上, 4 つの視点から, 関連する先行研究を整理する1)。

\section{III. 色相に着目した研究}

\section{1. 単色の効果に着目した研究}

色相に着目した研究を概観すると, 単色の効果に着目 した研究が多く存在する。本節では単色の効果に着目し た研究を，(1）色相がもたらす身体的反応に着目した研 究，(2) 色相によって喚起される意味が消費者の反応に 与える影響に着目した研究，そして，（3）対象となる製 品パッケージ等の色相と性別・社会活動などからイメー ジされる色相との一致に着目した研究の 3 つの観点に分 けてレビューする。

\section{（1）色相がもたらす身体的な反応に着目した研究}

Guido, Piper, Prete, Mileti, and Trisolini（2017）は, ス マートフォン上での製品購買に焦点を当て, スマートフォ ンから発せられる光や周囲の光の色と, 購買されやすい 製品の関倸を明らかにした。周辺光が白の条件下ではス マートフォンから発せられる光が青色の時に, スマート フォンから発せられる光が白色の条件下では周辺光が青 色の時に, 快楽的な製品の購入意向が高くなることを確 認した。Gudio らは，青色の光によって身体的にリラッ クスさせられることで快楽的な製品への志向が高まった ためであると述べている。

Das, Roy, and Spence（2020）は，制御焦点理論 2)を用 い，消費者の制御焦点と色相による覚醒度の一致がもた らす消費者反応を捕捉した。予防焦点の消費者は覚醒度 が低い平静状態を好むのに対し, 促進焦点の消費者は覚 醒度が高い陽気であることを好む。また，人は赤色を見 ることで覚醒度を高めることから，赤を見ることによる 覚醒と促進焦点の人の陽気さによる觉醒が一致すること で，サービスの失敗に対する負の感情を緩和すると Das らは考えた。そして, 赤あるいは青の背景色を用いた $\mathrm{EC}$ サイトで携带電話の購入を行うという調查を行いその影 響を確認した。結果, 携带電話の在庫切れというサービ スの失敗があった場合でも, 促進焦点の消費者において は，赤色の背景の EC サイトで購入したほうが，青色の EC サイトで購入するよりもサービス全体の満足を高く 評価した。 
（2）色相がもたらす意味が消費者の行動に与える影響に 着目した研究

赤は情熱や危険を，青は冷たさや未熟さを意味するよ うに，色が人々に特定の意味を喚起させることがある。 Pontes and Williams（2021）は，赤色がもたらす危険のイ メージに焦点を当て，赤色を見た人は，青色を見た人に 比べてリスク回避的になることを明らかにした。また， Pontes らは幸運のプライミングによる影響や赤色がもた らす文化的な意味の違いも検討し，幸運であるとプライ ミングされている消費者や，赤を幸せの象徵とする中国 人消費者は，赤色によるリスク回避の効果が低減するこ とも明らかにした。

人々は赤色を見ると，危険を想起するため, リスクを 回避しょうと念入りな行動をとるようになる。一方，赤 色を見ることで覚醒度が高まることから，習慣的な行動 が誘発され念入りな行動を取りにくくなる。これらの相 反する行動について, Mehta, Demmers, van Dolen, and Weinberg（2017）は，個人の刺激追求志向が調整するこ とを明らかにした。すなわち，刺激追求の志向性が高い 人ほど，赤がもたらす覚醒度に注意が向けられ，念入り な行動を取りにくくなり，刺激追求の志向が低い人には このような関係は見られなかった。

赤色は危険やリスク以外の意味も消費者に訴求する。 Ye, Bhatt, Jeong, Zhang, and Suri（2020）は，チラシ中に 表示される赤色の価格がもたらす扮得感に着目した。Ye らは，1つの製品価格のみ赤色で表記しているチラシと， 全ての価格を黒色で表記しているチラシを消費者に提示 し，全ての価格を黒色で表記しているチラシの店舗に対

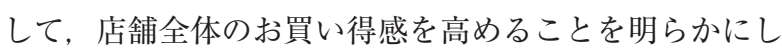
た。1つの価格だけが赤色で表示されている場合，その 製品にのみお買い得感を感じ，他の製品に対してお買い 得感を感じにくくなってしまったことが，このような結 果をもたらしたとYeらは推察している。

（3）色相と性別やマーケティング活動などからイメージ される色相との一致に着目した研究

Gill and Lei（2018）は，男性用フェイスクリームなど のような, 製品カテゴリーがターゲットとする消費者の 性別と異なる性別の消費者をターゲットとする製品にお
ける色の効果に着目した。男性を想起させる色である青 色を用いたパン焼きセット（女性向け製品）の購入意向 を男性に調査したところ, 男性は総じて, 青色のパン焼 きセットに対して好ましさを感じ，購入意向が高まった。 一方で女性を想起させる色であるピンク色の自動車修理 セット（男性向け製品）に対する購入意向を女性に問う たところ，購入意向には差が見られた。自身を女性らし いと答えた女性は，ピンク色の自動車修理セットを好ま しいと判断し購入意向を高めた。一方，女性らしさの度 合いが低い女性は，自動車修理セットに対し好ましさを 低く評価した。Gill らは，ピンク色が女性的であること を強く訴求してしまうため, 女性らしさの度合いが低い 女性にはピンク色という要素がかえってネガティブに働 き，彼女らの製品選好を高めることができなかったと結 論づけている。

Marozzo, Raimondo, Miceli, and Scopelliti（2020）は, 食品パッケージに抄ける自然色の効果を検討した。健康 的な食品のパッケージは，自然を彷彿とさせるべージュ などの色のほうが，混じり気がなく添加物が入っていな い食品であると消費者は知覚するため, 他の色のパッケー ジに比べ，消費者の支払意向価格を高めることを確認し た。一方で健康的ではない食品のパッケージにおいては, 色の違いが消費者の支払意向価格に影響を及ぼすことは なかった。

Kuo and Rice（2015）は，ピンク色と黄色のレモネー ドを用い，企業が取り組む CRM 活動としてピンクリボ ン運動 3$)$ と白血病を題材に, 消費者の慈善活動への意向 を確認した。そして，ピンク色のレモネードとピンクリ ボン活動の条件, すなわち製品色と CRM 活動から想起 される色が一致している時に，消費者の慈善活動意向を 高めることを確認した。

また Henderson, Mazodier, and Sundar（2019）は，ス ポーツチームの色とスポンサーの広告色の一致に着目し た。メジャーリーグの試合のデー夕を使用し，スポーッ チームと同じ色を用いた広告を見たファンは，広告スポ ンサーに対する評価を高めることを明らかにした。

\section{2. 配色に着目した研究}

本節では 2 つの色の関倸に着目した研究を整理する。 
Review Article レビュー論文ーシリーズ 131

印刷広告における製品色と背景色の配色に着目した Huang, Wang, Liu, and Yu（2020）は，製品の特徴によっ て製品色と背景色の配色の効果が変化することを明らか にした。ティッシュペーパーのような機能的製品の広告 では，製品色と背景色の関係が隣接色相配色の時に， ワ ンピースドレスのような感覚的・社会的製品 ${ }^{4)}$ の広告で は補色色相配色 ${ }^{5)}$ の時に, それぞれの製品評価が高くなっ た。Huang らは，購買時における消費者の情報処理プロ セスが製品によって異なるために，上記の結果をもたら したと結論づけている。つまり，機能的製品は製品選択 や購入判断時に熟慮が求められることから, 色の奇抜さ に目を取られない製品色と背景色が隣接色相配色になっ ている広告に対して消費者は好ましい評価を下した。一 方, 感覚的・社会的製品は, 自身の社会性や感覚的経験 に合致した製品であるかを容易に判断できるように製品 を目立たせる必要があるため, 製品色と背景色が明瞭に なる補色色相配色の広告を好ましく判断したのである。

また，ロゴマークの配色に着目したJeon, Han, and Nam （2020）は, 隣接色相配色と補色色相配色の 2 つの配色 と文化的自己観の関係を明らかにした。調和や類似に着 目する相互協調的自己観が高い人は隣接色相配色のロゴ マークを好むことが確認された。一方，物事を分離して 考える傾向のある相互独立的自己感が高い人は, ロゴマー クの色の 1 つ つをそれぞれ別個に捉えるため, 2 種類 のロゴマークの選好に違いはみられなかった。

\section{IV. 明度と彩度に着目した研究}

\section{1. 明度に着目した研究}

明度の高いものは軽く, 低いものは重く知覚する (Alexander \& Shansky, 1976)。この明度の高低がもたらす 重量感の知覚の変化を援用した消費者行動研究は複数存 在する。

Sunaga, Park, and Spence（2016）は，製品パッケージ の明度の高低と製品の陳列位置の関係を検討した。陳列 棚の上部に陳列された製品は軽く，下部に陳列された製 品は重く知覚することから, 製品パッケージの明度と陳 列位置の一致が消費者にもたらす影響を見た。明度の高
い製品パッケージを上部に, 明度の低い製品パッケージ を下部に陳列する，つまり明度と陳列位置が一致した製 品陳列を見た消費者は，不一致状態の製品陳列を見た消 費者に比べ，製品の探しやすさ，製品の選択しやすさ及 び，支払意向価格を高く評価した。

重さの知覚が, 製品の頑丈さや耐久性に影響を与える ことに着目した Hagtvedt（2020）は，明度の低い製品を 重い製品であると知覚し，その結果耐久性が高い製品で あると消費者が判断することを確認した。また，製品の 明度が高くなることで軽さを知覚するため, 明度が高い 製品を操作が容易な製品であると消費者が知覚すること も明らかにした。

Mai, Symmank, and Seeberg-Elverfeldt（2016）は，ピザ やヨーグルトなどのパッケージを用い, パッケージの明 度が高まることで健康の知覚に対して正の影響を，おい しさの知覚に対して負の影響を与えることを明らかにし た。明度が高まることで消費者は, 食品に含まれる成分 のうち脂肪分や糖分を少なく知覚するため, より健康的 な食品であると判断する。一方, 明度が高まることで, 濃厚感や熟成感を知覚しにくくなり，おいしさの知覚を 低下させたと彼らは解釈している。また，健康に対する 意識が低い消費者や製品利用のない消費者において，こ れら 2 つ効果が強くなることが示された。

重さの知覚以外の点から明度の違いが消費者に与える 影響を検討した研究に, Reynolds-McIlnay, Morrin, and Nordfältt（2017）がある。彼らは, 製品と周辺環境の明度 のコントラストに着目し, 周辺環境の明度とコントラス トのある製品の選択確率が高まることを確認した。製品 と周辺環境の明度にコントラストがあると製品が目立つ ため，製品選択確率が高まったと考察している。

また, Hagtvedt and Brasel（2016）では, 明度と周波 数の一致の効果を検討し，周波数が高い（低い）音を聞 いている消費者は，明度が高い（低い）ロゴを注視する ことが確認されている。

明度が最も高くなると白色になり, 最も低くなると黒 色になる。この白や黒の意味に着目した Chan and Meng （2021）は, 購入する製品の色とその後の慈善行動との 関連を明らかにした。そして, 白色の製品を選択した人 に比べ，黒色の製品を選択した人のほうが，自然保護団 
体に対してより高額な寄付を行うことを見いだした。白 色の製品の購入した人は，道徳的に好ましい行動をとっ たと感じ，道德的行動を行った後には自身に甘い行動を とるというセルフライセンシングの効果が働いたため, 寄付額が少なかった。他方で，黒色の製品を購入した人 は，道徳的に好ましくない行為をとったと感じてしまい， それを補正するために慈善団体への寄付額を高くしたと Chan らは説明している。

\section{2. 彩度に着目した研究}

色の鮮やかさを示す彩度は消費者の覚醒との関連が強 く，彩度が高い対象を見た消費者は彩度が低い対象を見 たときよりも覚醒度を高める。この明度がもたらす覚醒 度と製品の所有期間に着目した研究が， Buechel and Townsend（2018）である。50 種類の製品を用い，所有 期間が長くなる製品であるほど彩度の高い製品の選択確 率が下がるという関係を明らかにした。彩度が高い製品 を目にするたびに覚醒度が高まり，頻繁に覚醒させられ ることで消費者に不快感が生まれる。そのため, 製品を 目にする機会が増加する所有期間が長い製品においては, 彩度が高い製品が選ばれにくくなると彼らは主張して いる。

Hagtvedt and Brasel（2017）は，彩度の高低が製品サ イズの知覚に与える影響を検討した。消費者は彩度が高 い製品に対して注意を向け，その製品を大きく知覚する ことから，彩度が高い製品を好ましく評価することを明 らかにした。さらに Hagtvedt らは，製品の利用目的に よって選好が変化することも確認している。キャリーケー 久を用いた調查で，収容量が多いほうが好ましいシナリ オを読んだグループは彩度が高い方を，手頃な大きさが 好ましいシナリオを読んだグループは，彩度が低いキャ リーケースを選択することを示した。

Wang, Qian, and Li（2020）は, 上記の研究を発展させ, 周波数が，彩度によってもたらされる製品の大きさの知 覚を調整することを明らかにした。すなわち，周波数が 高い音を聞いている消費者のみ，彩度の高さが製品の大 きさに影響を及ぼすことを確認した。

彩度に関する研究では, 味覚との関係を捉えた研究も 挙げられる。Kunz, Haasova, and Florack（2020）は,
ジュースのパッケージ写真の彩度を高めることで新鮮さ の知覚が高まり, 健康さや扔いしさの知覚が向上する確 認した。

また，味覚との関倸を明らかにした他の研究に，酸味 が消費者の誘惑回避行動に与える影響を調整する变数と して, 彩度の変化を用いた Pomirleanu, Gustafson, and Bi （2020）の研究も挙げられる。彩度が低い条件では, ぶ どう（酸味のない果物）の写真よりもライム（酸味のあ る果物）の写真を見た消費者の方が誘惑を回避すること が確認された。さらに, 同じライムの写真であっても, 彩度が高い写真を見た消費者のほうが誘惑に駆られやす くなった。彼らはこの結果を, 消費者が味覚よりも視覚 を優先するという点から説明している。すなわち, 写真 の彩度が高まることで味覚よりも視覚刺激が優先され， 高い彩度が覚醒度を高めることから, 消費者の誘惑回避 行動意図が低減したと述べている。

\section{V. モノクロ対カラーに着目した研究}

印刷広告や新聞広告などではカラー広告だけではなく モノクロ広告を用いることもある。このモノクロとカラー を比較し，その効果を検討した研究も見られる。例えば， Lee, Fujita, Deng, and Unnava（2017）は，モノクロとカ ラーの関倸について解釈レベル理論 6)を用いて検討した。 空飛ぶサーフィンボードのプロトタイプが明日（あるい は 5 年後）完成するという記事を実験参加者に読ませ, サーフィンボードの写真をカラー（あるいはモノクロ） で見せた時の効果を検討した。時間的距離が近い，明日 完成するという記事を読んだグループはカラー写真の サーフィンボードに, 時間的距離の遠い，5年後に完成 するという記事を読んだグループはモノクロ写真のサー フィンボードに対して支払い意向額が高くなる傾向を示 し，製品にも好ましい評価を下すことが確認された。

Lee らの研究を発展させた Wang, Liu, Kandampully, and Bujisic（2020）は, レストランの広告を用い，色の有無 とメッセージの訴求内容について解釈レベル理論の観点 から検討した。そして, おいしさを訴求したメッセージ の広告はカラー広告の方が, 健康面を訴求したメッセー 
ジの広告はモノクロ広告のほうが, 広告への態度が高ま ることを確認した。また，そのメカニズムとして納得感 （feeling right）を挙げ, 色の有無とメッセージが一致し た広告は納得感が高まり，その結果として広告への評価 を高めることを見出した。Wang らはこの結果について， メッセージが訴求する便益までの時間的距離の観点から 説明している。おいしさという便益は即時的に得られる のに対し，健康という便益は得られるまでに時間を要す る。この関係を解釈レベル理論の視点から説明すると, おいしさは便益を得るまでの時間的距離が近く低次の解 䣋レベルに対応する。一方，健康は便益を得るまでの時 間的距離が遠くなるため, 高次の解釈レベルと関連が強 い。つまり，解釈レベルを通じて考えると，おいしさの 訴求とカラー広告は低次の解釈レベルという点で, 健康 の訴求とモノクロ広告は高次の解釈レベルとマッチする ため, 納得感が発生したと結論づけている。

モノクロとカラーに焦点を当てた研究は, 解釈レベル 理論に関連した研究以外にも存在する。Wedel and Pieters （2015）は, 広告上の写真のピンぼけ色の有無の関係 を検討しており, 典型的な広告がピンぼけしている場合, モノクロ広告よりもカラー広告のほうが，広告の識別率 が高まることを確認した。また, Kim, Spence, and Marshall （2018）は，製品情報がモノクロで表示されている時よ りもカラーで表示されている時に, 妥協効果が発生する ことを明らかにした。Kim らは製品情報がカラーで記載
されることで, 処理すべき情報量が増え, 認知資源が枯 渇しやすくなることから，消費者は単純化した回答をし ようとするために妥協効果が発生しやすくなると説明し ている。

\section{VI. まとめと今後の研究課題}

本論文では, 色が消費者にもたらす影響に着目した研 究について 2015 年以降の論文を整理した。主な論文を, マーケティングミックスの視点と視覚刺激である色の変 化が味覚や聴覚など他の感覚に影響を与えるというクロ スモーダルの視点からそれぞれまとめると表 1 及び表 2 となる。表 1 を見ると, 色相に関する研究はマーケティ ングミックスのすべての要素で検討がなされていること が確認できる。一方で, 明度や彩度に着目した研究を見 ると, 明度に関する研究では製品と流通チャネル, 彩度 に関する研究では製品に着目した研究しか, 今回のレ ビューした範囲では確認できなかった。また，色とクロ スモーダル効果の関係を見てみると（表 2), 聴覚や味 覚, 触覚との関係に着目した研究は挙げられるものの, 嗅覚との関係に着目した研究は今回のレビューの範囲で は確認できなかった。

ここまで整理した 2015 年以降の色彩研究における潮 流から確認できる今後の課題を 3 点挙げる。 1 点目の課

\begin{tabular}{|c|c|c|c|c|}
\hline & 製品 & 価格 & 流通チャネル & プロモーション \\
\hline 色相 & $\begin{array}{l}\text { • 性別イメージとの一致 } \\
\text { (Gill \& Lei, 2018) } \\
\cdot \text { CRM 活動から想起される色 } \\
\text { (Kuo \& Rice, 2015) }\end{array}$ & • チラシ上の効果（Ye et al., 2020） & - 周辺光の色 (Guido et al., 2017) & $\begin{array}{l}\text { • サービスの失敗後の消費者満足 } \\
\text { (Das et al., 2020) } \\
\text { •ロゴマークの配色 } \\
\text { (Jeon et al., 2020) } \\
\text { • 製品色と広告の背景色の関係 } \\
\text { (Huang et al., 2020) }\end{array}$ \\
\hline 明度 & $\begin{array}{l}\cdot \text { 耐久性・操作性 } \\
\text { (Hagtvedt, 2020) } \\
\cdot \text { 購買後の道德的行動 } \\
(\text { Chan \& Meng, 2021) }\end{array}$ & & $\begin{array}{l}\text { ・陳列位置 (Sunaga et al., 2016) } \\
\text { • 周辺環境とのコントラスト } \\
\text { (Reynolds-McIlnay et al., 2017) }\end{array}$ & \\
\hline 彩度 & $\begin{array}{l}\text { • 使用期間 } \\
\text { (Buechel \& Townsend, 2018) }\end{array}$ & & & \\
\hline $\begin{array}{l}\text { モノクロ } \\
\text { 対カラー }\end{array}$ & & & & $\begin{array}{l}\text { • 広告メッセージとの一致 } \\
\text { (B. Wang et al., 2020) } \\
\text { •広告のぼかしの効果 } \\
\text { (Wedel \& Pieters, 2015) }\end{array}$ \\
\hline
\end{tabular}




\begin{tabular}{|c|c|c|c|c|}
\hline & 触覚 & 味覚 & 聴覚 & 嗅覚 \\
\hline 色相 & & · 健康志向（Marozzo et al., 2020） & & \\
\hline 明度 & \begin{tabular}{|l} 
- 耐久性と操作性（Hagtvedt, 2020) \\
- 陳列位置（Sunaga et al., 2016）
\end{tabular} & $\begin{array}{l}\text { • 美味しさと健康さの知覚 } \\
\text { (Mai et al., 2016) }\end{array}$ & $\begin{array}{l}\text { •周波数とロゴの注視 } \\
\text { (Hagtvedt \& Brasel, 2016) }\end{array}$ & \\
\hline 彩度 & & $\begin{array}{l}\text { • 美味しさと健康さの知覚 } \\
\text { (Kunz et al., 2020) } \\
\text { ・酸味による誘惑回避行動の調整 } \\
\text { 効果 (Pomirleanu et al., 2020) }\end{array}$ & $\begin{array}{l}\text { - 周波数と製品サイズ } \\
\text { (L. Wang et al., 2020) }\end{array}$ & \\
\hline $\begin{array}{l}\text { モノクロ } \\
\text { 対カラー }\end{array}$ & & $\begin{array}{l}\text { ·美味しさ・健康志向と解釈レベル } \\
\text { 理論 (B. Wang et al., 2020) }\end{array}$ & & \\
\hline
\end{tabular}

出典：筆者作成

題は，色相に関する研究のうち，配色に着目した研究が 限られている点である。多くの製品パッケージや広告で は複数の色が用いられているにもかかわらず, 配色に関 するマーケテイング的な側面からの研究は数少ない。本 論文がレビューの対象とした 2015 年以前から配色に関 する研究の重要性が説かれている（Labrecque, Patrick, \& Milne, 2013) 一方で, この点からの知見が 2015 年以降の 論文においても少ないことから，検討すべき課題である と言えよう。

2 点目の課題は, 明度・彩度に関する近年の研究にお いて，特定のマーケティングミックスの要素に着目した 研究しか取り組まれていない点である。表 1 を見ると, 今回のレビューの範囲において，明度に関する研究は製 品及び流通チャネル, 彩度に関する研究では製品のみと, 限られた範囲での研究しか存在しないことがわかる。ま た，明度や彩度が消費者に与える影響について，重さの 知覚や覚醒度に着目し, その点を軸として消費者に与え る影響を検討する研究が多かった。明度や彩度に関する 研究は，その重要性が高いにもかかわらず，色相に関す る研究ほどは精力的に研究が進められていないという問 題もある（Labrecque et al., 2013）。この点から見ても, 複数の異なる視点から価格やプロモーションなどを含め た様々なマーケティングミックスの要素との関係性を明 らかにすることで, 明度や彩度の変化に関する, より深 い知見が得られると推察できる。

3 点目の課題は, 色が嗅覚に与える影響を検討した研 究が今回のレビューの範囲内で存在しない点である。表 2 を見ると, 色と味覚, 聴覚の相互作用に関する研究や,
触覚に関連する重さを対象とした研究は存在するが, 嗅 覚とのクロスモーダル効果に関する消費者行動研究は, 今回レビューした範囲では見られない。一方, 色彩に関 する研究領域では色相と香りの調和に関する研究も存在 する (Miura \& Saito, 2006)。このような研究を援用し, 消費者行動分野における色と嗅覚のクロスモーダルに着 目した研究が, 今後期待される。

最後に本論文の課題として以下の点が挙げられる。本 論文は 2015 年以降の論文に絞りレビューを行ったため, 色に関する消費者行動研究領域の論文を網羅的にレ ビューできていない。この点が本論文の課題であり, 全 体的な研究動向を把握することが望まれる。

\section{謝辞}

本論文の作成にあたって, レビュアーの先生より貴重 なコメントを頂戴いたしました。ここに記して謝意を表 させていただきます。また, 本研究は JSPS 科研費 20K22106 の助成を受けたものです。

注

1）レビューの対象となる論文の選定は以下の方法で行った。 Web of Science を用い, トピックとして Color, Hue, Brightness, Value, Saturation, Chroma のいずれかと Marketing, Consumerのいずれかの単語を組み合わせて検索 した。検索結果のうち 2015 年以降に Journal of Marketing, Journal of Consumer Research, Journal of Retailing, Journal of Marketing Research, Marketing Science, Journal of Consumer Psychology, Psychology and Marketing, Journal of Advertising より発行された論文を本論文では取り上げる。

2）制御焦点理論では, 目標に対する焦点の違いが人々の行動 に影響を与えると考えられており，ポジティブな結果の有 無に注目する促進焦点とネガティブな結果の有無に注目す 
る予防焦点に分けられる (Higgins, 1997; Ishii, 2018)。

3）乳がんの早期発見や治療を目的とした活動。

4） Roth（1995）は，ブランドが消費者に与えるイメージを機 能的イメージ, 感覚的イメージ, 社会的イメージに分類し, 機能的イメージは感覚的イメージや社会的イメージとの間 に負の相関を持ち, 機能的イメージと感覚的イメージは正 の相関を持つことを確認した。この結果から, Huang らは, 機能的製品と社会的・感覚的製品に分割し研究を行った。

5）赤と橙のように 2 色の色相差が小さい配色を隣接色相配色 といい，赤と緑のように 2 色の色相差が大きい配色を補色 色相配色という。

6）人々が対象や出来事に対して感じる心理的距離の遠近に よって, 精神的表象が異なることを示した理論。心理的距 離が遠いときに抽象的・本質的な高次の解釈，近いときに 具体的・副次的な低次の解釈が行われる (Abe, Moriguchi, \& Yashima, 2015; Trope \& Liberman, 2003)。

\section{References}

Abe, M., Moriguchi, T., \& Yashima, A. (2015). Senkou no gyakuten: Kaisyakureberuriron ni waribiki no gainenn wo kumikonda moderu niyoru bunseki. Koudoukeizaigaku, 8, 1-12. doi: 10.11167/jbef.8.1（阿部誠・守口剛・八島明朗 (2015)。「選 好の逆転 : 解釈レベル理論に割引の概念を組み込んだモデ ルによる分析」『行動経済学』8,1-12) (In Japanese)

Alexander, K. R., \& Shansky, M. S. (1976). Influence of hue, value, and chroma on the perceived heaviness of colors. Perception \& Psychophysics, 19(1), 72-74. doi: 10.3758/bf03199388

Buechel, E. C., \& Townsend, C. (2018). Buying beauty for the long run: (Mis) predicting liking of product aesthetics. Journal of Consumer Research, 45(2), 275-297. doi: 10.1093/jcr/ucy002

Chan, E. Y., \& Meng, Y. (2021). Color me moral: White and black product colors influence prosocial behaviors. Psychology \& Marketing, 38(1), 212-224. doi: 10.1002/mar.21435

Das, G., Roy, R., \& Spence, M. T. (2020). The mitigating effect of matching regulatory focus with arousal - inducing stimuli in service failure situations. Psychology \& Marketing, 37(10), 1420-1432. doi: 10.1002/mar.21390

Elliot, A. J. (2015). Color and psychological functioning: A review of theoretical and empirical work. Frontiers in Psychology, 6, 368. doi: $10.3389 /$ fpsyg.2015.00368

Gill, T., \& Lei, J. (2018). Counter - stereotypical products: Barriers to their adoption and strategies to overcome them. Psychology \& Marketing, 35(7), 493-510. doi: 10.1002/mar.21101

Guido, G., Piper, L., Prete, M. I., Mileti, A., \& Trisolini, C. M. (2017). Effects of blue lighting in ambient and mobile settings on the intention to buy hedonic and utilitarian products. Psychology \& Marketing, 34(2), 215-226. doi: 10.1002/mar. 20984

Hagtvedt, H. (2020). Dark is durable, light is user - friendly: The impact of color lightness on two product attribute judgments. Psychology \& Marketing, 37(7), 864-875. doi: 10.1002/mar. 21268

Hagtvedt, H., \& Brasel, S. A. (2016). Cross-modal communication: Sound frequency influences consumer responses to color lightness. Journal of Marketing Research, 53(4), 551-562. doi: 10.1509/jmr.14.0414

Hagtvedt, H., \& Brasel, S. A. (2017). Color saturation increases perceived product size. Journal of Consumer Research, 44(2), 396-413. doi: 10.1093/jcr/ucx039

Henderson, C. M., Mazodier, M., \& Sundar, A. (2019). The color of support: The effect of sponsor-team visual congruence on sponsorship performance. Journal of Marketing, 83(3), 50-71. doi: 10.1177/0022242919831672

Higgins, E. T. (1997). Beyond pleasure and pain. American Psychologist, 52(12), $1280-1300$. doi: 10.1037/0003-066x. 52.12 .1280

Huang, J., Wang, Z., Liu, H., \& Yu, L. (2020). Similar or contrastive? Impact of product-background color combination on consumers' product evaluations. Psychology \& Marketing, 37(7), 961-979. doi: 10.1002/mar.21361

Ishii, H. (2018). Optimum amount of information on a package: Effects of regulatory focus and perceived information excess on the consumer response. Japan Marketing Journal, 38(2), 21-38. doi: 10.7222/marketing.2018.038（石井裕明 (2018). 「パッケージにおける最適な情報量 : 制御焦点と情報過剩感 による影響」『マーケティングジャーナル』38(2), 21-38) (In Japanese with English abstract)

Jeon, E., Han, Y., \& Nam, M. (2020). How you see yourself influences your color preference: Effects of self - construal on evaluations of color combinations. Psychology \& Marketing, 37(7), 980-994. doi: 10.1002/mar.21348

Kim, J., Spence, M. T., \& Marshall, R. (2018). The color of choice: The influence of presenting product information in color on the compromise effect. Journal of Retailing, 94(2), 167-185. doi: 10.1016/j.jretai.2018.01.002

Krishna, A. (2012). An integrative review of sensory marketing: Engaging the senses to affect perception, judgment and behavior. Journal of Consumer Psychology, 22(3), 332-351. doi: 10.1016/j.jcps.2011.08.003

Kunz, S., Haasova, S., \& Florack, A. (2020). Fifty shades of food: The influence of package color saturation on health and taste in consumer judgments. Psychology \& Marketing, 37(7), 900912. doi: 10.1002/mar.21317

Kuo, A., \& Rice, D. H. (2015). The impact of perceptual congruence on the effectiveness of cause-related marketing campaigns. Journal of Consumer Psychology, 25(1), 78-88. doi: 10.1016/j.jcps.2014.06.002

Labrecque, L. I. (2020). Color research in marketing: Theoretical and technical considerations for conducting rigorous and impactful color research. Psychology \& Marketing, 37(7), 855863. doi: 10.1002/mar.21359

Labrecque, L. I., Patrick, V. M., \& Milne, G. R. (2013). The marketers' prismatic palette: A review of color research and future directions. Psychology \& Marketing, 30(2), 187-202. doi: 10.1002/mar.20597

Lee, H., Fujita, K., Deng, X., \& Unnava, H. R. (2017). The role of temporal distance on the color of future-directed imagery: A construal-level perspective. Journal of Consumer Research, 
43(5), 707-725. doi: 10.1093/jcr/ucw051

Mai, R., Symmank, C., \& Seeberg-Elverfeldt, B. (2016). Light and pale colors in food packaging: When does this package cue signal superior healthiness or inferior tastiness? Journal of Retailing, 92(4), 426-444. doi: 10.1016/j.jretai.2016.08.002

Marozzo, V., Raimondo, M. A., Miceli, G. N., \& Scopelliti, I. (2020). Effects of au naturel packaging colors on willingness to pay for healthy food. Psychology \& Marketing, 37(7), 913-927. doi: 10.1002/mar.21294

Mehta, R., Demmers, J., van Dolen, W. M., \& Weinberg, C. B. (2017). When red means go: Non-normative effects of red under sensation seeking. Journal of Consumer Psychology, 27(1), 91-97. doi: 10.1016/j.jcps.2016.04.004

Miura, K., \& Saito, M. (2006). Flavor classification and matched combination with color. Journal of the Color Science Association of Japan, 30(4), 184-195. (三浦久美子・齋藤美穂（2006）. 「香りの分類及び調和色の検討」『日本色彩学会誌』30(4), 184-195) (In Japanese)

Ohyama, T., \& Saito, M. (Eds.). (2009). An introduction to color theory: "Kansei" and the psychology of color. Tokyo: University of Tokyo Press.（大山正・斎藤美穂（編）（2009）。色彩学 入門 : 色と感性の心理』東京大学出版会)

Pomirleanu, N., Gustafson, B. M., \& Bi, S. (2020). Ooh, that's sour: An investigation of the role of sour taste and color saturation in consumer temptation avoidance. Psychology \& Marketing, 37(8), 1068-1081. doi: 10.1002/mar.21363

Pontes, N., \& Williams, L. K. (2021). Feeling red lucky? The interplay between color and luck in gambling settings. Psychology \& Marketing, 38(1), 43-55. doi: 10.1002/mar.21408

Reynolds-McIlnay, R., Morrin, M., \& Nordfält, J. (2017). How product - environment brightness contrast and product disarray impact consumer choice in retail environments. Journal of Retailing, 93(3), 266-282. doi: 10.1016/j.jretai. 2017.03.003

Roth, M. S. (1995). The effects of culture and socioeconomics on the performance of global brand image strategies. Journal of Marketing Research, 32(2), $163-175$. doi: 10.1177/ 002224379503200204

Sunaga, T., Park, J., \& Spence, C. (2016). Effects of lightness location congruency on consumers' purchase decision making. Psychology \& Marketing, 33(11), 934-950. doi: 10.1002/mar.20929

Trope, Y., \& Liberman, N. (2003). Temporal construal. Psychological Review, 110(3), 403-421. doi: 10.1037/0033-295x.110.3.403

Wang, B., Liu, S. Q., Kandampully, J., \& Bujisic, M. (2020). How color affects the effectiveness of taste-versus health-focused advertising messages. Journal of Advertising, 49(5), 1-18. doi: 10.1080/00913367.2020.1809575

Wang, L., Qian, D., \& Li, O. (2020). The cross - modal interaction between sound frequency and color saturation on consumer's product size perception, preference, and purchase. Psychology \& Marketing, 37(7), 876-899. doi: 10.1002/mar.21284

Wedel, M., \& Pieters, R. (2015). The buffer effect: The role of color when advertising exposures are brief and blurred.
Marketing Science, 34(1), $134-143$. doi: 10.1287/mksc. 2014.0882

Ye, H., Bhatt, S., Jeong, H., Zhang, J., \& Suri, R. (2020). Red price? Red flag! Eye - tracking reveals how one red price can hurt a retailer. Psychology \& Marketing, 37(7), 928-941. doi: 10.1002/ mar.21331

\section{河股 久司（かわまたひさし）}

早稲田大学商学部講師 (任期付)。2021 年早稲田大学大学 院商学研究科博士後期課程単位取得。早稲田大学商学部助 手を経て，2021 年 9 月より現職。修士 (商学)。専門は消 費者行動。 